\title{
MAPPING THE MUSEOLOGY OF EDUCATION IN SPAIN: AN EXAMINATION OF WHERE THE ISSUE CURRENTLY STANDS 1
}

DOI: http://dx.doi.org/10.1590/2236-3459/75395

\author{
Pablo Álvarez Domínguez'
}

'Universidad de Sevilla (US), Sevilla, España

$\cos 80$

\begin{abstract}
In the past two decades, the museology of education in Spain has been one of the most attractive, productive avenues of educational historical research. With new focuses, education museums have come to be understood as essential resources for research and teaching in this area. A study of the relationship between the Museology of Education and History of Education offers a field of research which feeds into the study of Spain's historical educational heritage. This article approaches the Museology of Education as the most promising research area for historiographers of education in Spain. From the very start, it sets out the main actions, activities and projects in museology taking place in the country, which demonstrate how historical educational science has taken ethnohistory in a new direction.

Keywords: history of education, museology of education, museums of education, pedagogy and teaching, historical educational heritage.
\end{abstract}

\section{MAPEAMENTO DA MUSEOLOGIA DA EDUCAÇÃO NA ESPANHA: APROXIMAÇÃO AO ESTADO DA QUESTÃO}

\begin{abstract}
Resumo
Nas últimas décadas, a Museologia da Educação tem se apresentado na Espanha como uma das mais atraentes linhas de pesquisa histórico-educativas. Novos enfoques nos têm permitido traçar um mapa no qual os Museus de Educação são entendidos como recursos imprescindíveis para a pesquisa e para a docência nesta matéria. A relação entre Museologia e História da Educação nos permite vislumbrar um panorama de pesquisa alentador no estudo do patrimônio histórico educativo. O presente artigo pretende aproximar-se à Museologia da Educação como campo de pesquisa para os historiadores da educação na Espanha. A partir de suas origens, expõem-se as principais ações, atividades e projetos museológicos que estão se desenvolvendo no país, e que evidenciam a guinada da ciência histórico-educativa em direção à etno-história. Palavras-chave: história da educação, museologia da educação, museus da educação, pedagogia e ensino, patrimônio histórico-educativo.
\end{abstract}

\footnotetext{
1 This work draws inspiration from "Beca José Castillejo". Ministerio de Educación, Cultura y Deporte del Gobierno de España. Resolución de 19 de abril de 2013, de la Secretaría de Estado de Educación, Formación Profesional y Universidades, por la que se conceden subvenciones de la Modalidad B del Programa de estancias de movilidad de profesores e investigadores españoles en centros extranjeros.
} 


\section{MAPEO DE LA MUSEOLOGÍA DE LA EDUCACIÓN EN ESPAÑA: APROXIMACIÓN AL ESTADO DE LA CUESTIÓN}

\section{Resumen}

En las últimas dos décadas, la Museología de la Educación se presenta en España como una de las líneas de investigación histórico educativa más atrayente. Nuevos enfoques nos han permitido trazar un mapa en el que los Museos de Educación se entienden como imprescindibles recursos para la investigación y la docencia en esta materia. La relación entre Museología de la Educación e Historia de la Educación nos permite vislumbrar un panorama investigador alentador en el estudio del patrimonio histórico educativo. El presente artículo pretende aproximarse a la Museología de la Educación como campo de investigación para los historiadores de la educación en España. En él, desde sus orígenes, se exponen las principales acciones, actividades y proyectos museológicos que se están desarrollando en el país, y que evidencian el giro que la ciencia histórico-educativa ha dado hacia la etnohistoria.

Palabras clave: historia de la educación, museología de la educación, museos de educación, pedagogía y enseñanza, patrimonio histórico educativo.

\section{CARTOGRAPHIE DES MUSEES DE L'ÉDUCATION EN ESPAGNE: ETAT DES LIEUX}

\section{Résumé}

Au cours des deux dernières décennies, Muséologie Education se présente en Espagne comme l'une des lignes de recherche historico-éducative la plus attractive. De nouvelles approches nous ont permis de cartographier les Musées de l'Education reconnus comme des ressources essentielles pour la recherche et l'enseignement dans ce domaine. Le lien entre Muséologie Education et Histoire de l'Education nous permet d'entrevoir un panorama de recherche encourageant dans l'étude du patrimoine historico-éducatif. Cet article vise à aborder Muséologie Education en tant que domaine de la recherche pour les historiens de l'éducation en Espagne. Dans ce document, depuis leurs origines, on expose les principales actions, activités et projets muséologiques en cours de développement dans le pays et qui démontrent le tournant pris par la science historico-éducative vers l'ethnohistoire.

Mots-clés: histoire de l'éducation, muséologie education, musées de l'education, pédagogie et enseignement, patrimoine historico-éducatif. 


\section{Introduction}

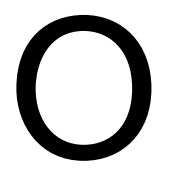

ver the past few years, society at large has been undergoing difficult transformations. The advances of science and technology have transformed what it means to be human in today's world, and the nature of social relations. Education and culture, the meaning and scope of which have been greatly extended, are essential for the development of individuals and of society as a whole. We know that all cultures are part of humanity's shared heritage. The cultural identity of a people is renewed and enriched by contact with the traditions and values of others. Culture is dialogue, the exchange of ideas and experiences, the appreciation of other values and traditions, and hence, it withers and dies when it is isolated. (DECLARACIÓN DE MÉXICO SOBRE LAS POLÍTICAS CULTURALES, 1982). The rationale for the projects being carried out in Spain is based on the premise that all peoples have the right and obligation to defend and preserve their cultural heritage - especially since the founding, in 2004, of the Sociedad Española para el Estudio del Patrimonio Histórico Educativo (Sephe). It includes the protection, conservation, study, investigation and recovery of our historical educational heritage. It is also concerned with activities that promote, stimulate, support and disseminate these goals. Many people are working hard on co-operating for the advancement of historical educational knowledge, the development of new museum-based focuses, and the promotion of all that can be learned from people's memories and the heritage of school culture. (MEDA; BADANELLI, 2013).

Important studies on its historical educational heritage have originated in Spain in the past decade. (ESCOLANO BENITO; HERNÁNDEZ DÍAZ, 2002; ESCOLANO BENITO, 2007; JUAN BORROY, 2008; LÓPEZ MARTÍN, 2013; MORENO MARTÍNEZ, 2009; 2015; RUÍZ BERRIO, 2009). The country is now recognised as being amongst those which are taking special interest in the material - and non - material historical reconstruction of the memory of education. The role being played by ethnohistory and the social history of education in the construction of today's historical-educational processes has led Spain's education historians - in line with those of several other countries - to pay particularly close attention to interpreting the school culture of the past. They are doing so by analysing the teaching materials used, school furniture, school buildings, school textbooks, accounts of people's schooldays, etc.

There are a variety of actions involved in Spanish society's commitment to the history of education, relating to the study and dissemination of people's memories of education. There have been many research projects; congresses, conferences and seminars have been held on the topic; temporary, roving exhibitions have been set up; various doctoral theses have been defended on the subject, and many undergraduate- and pre-doctoral dissertations have been written (an academic career in Spain includes an intermediary research viva between undergraduate and doctoral work); a number of projects aimed at innovating and improving pedagogical practices have been implemented; a large number of books, journal articles and exhibition catalogues have been published; and so on. This stands in evidence of Spain's healthy tradition of research into historical educational heritage. (MEDA; BADANELLI, 2013).

Particularly in the past fifteen years, the study of educational heritage has gained standing in the country as an emerging discipline in its own right. It has given rise to an extensive body of theoretical knowledge, along - as we have seen - with numerous projects, 
programmes, actions and practices originating in various educational environments (universities, in particular). The copious numbers of publications recorded in Spain about educational heritage and memories of education form an epistemological corpus which is increasingly large and along similar lines to significant corpora being compiled elsewhere in the world. In this paper, we enumerate and indeed elucidate many of the plans, processes, tasks and people in Spain contributing to the dissemination and public awareness of historical educational heritage.

Furthermore, in the past four decades, we have seen a huge increase in education museums. In Spain, in the rest of Europe and in America (RUíZ BERRIO, 2006), these institutions have made conscientious efforts to encourage the construction of a historical educational perspective in our time, through the conservation and promotion of what has been handed down to us from the schooling systems of the past. Gone, fortunately, are the $19^{\text {th }}$-Century museums which built collections for collection's sake, catering almost exclusively for an erudite, privileged audience; gone, too, are the exhibitions of sacred objects, viewed as guidance for the culture and conduct of a society; and the centralising museum structures and traditional single-discipline methods have fallen by the wayside. Today, various political bodies, and universities in particular, are implementing significant initiatives in museology with the aim of preserving our educational heritage, exhibiting it in a dignified fashion and disseminating knowledge of it. At the time of writing, in the case of Spain, we could count around sixty pedagogical museology initiatives, of varying type, character, size and impact. (ÁLVAREZ DOMÍNGUEZ, 2016a; 2016b) ${ }^{2}$. This is without including the well-known collections of school materials passed on through private initiatives. The tradition of historical educational heritage in our society today points towards a healthy future.

Museology of Education and the current education museums in Spain are committed in their drive to salvage and display a significant sample of the country's educational heritage. These artefacts are effective tools for helping to ensure the fundamental human right of access to culture and respect for cultural diversity, as set out in the Plan Nacional de Educación y Patrimonio (2013) published by the Instituto del Patrimonio Cultural de España. It should also be noted that, in Spain, there is a great deal of work being done on the didactic use of historical educational heritage. In particular, there is the role played by the teaching departments in educational museums, as well as the pedagogical activity taking place in early learning centres, primary schools, secondary schools (SOMOZA, 2011) and universities. Especially important are the pedagogical practices employed in universities for teaching or learning the History of Education at Educational Science faculties, designed to raise public awareness of the need to study and revitalise our educational heritage. (PAYÀ; ÁLVAREZ, 2013). In addition, the growing role of ICT (information and communication technology) in Spain is ensuring the dissemination and transfer of that heritage through the worldwide web. (ALVAREZ; PAYÀ, 2013; PAYÀ; ÁLVAREZ, 2015).

In this article, we list the main paths that have been following and the most important actions going on in Spain to renew and push forward the study and dissemination of the

\footnotetext{
2 In this regard, the author suggests consulting the virtual map of museums and educational heritage centres in Spain: <http://www.patrimonioeducativo.es/2011/12/centros-de-patrimonio-educativo-espanol.html>. Last accessed: 24 May 2017.
} 
country's educational heritage, with the intention of showing how the historiography of educational heritage in Spain is experiencing noteworthy advances.

\section{Beginnings and edification of Museology of Education in Spain. The leading role played by the study of historical educational heritage}

Since its very beginnings, History of Education - which arose, as an academic discipline, in the 19th Century for the training of teachers - has always been a controversial field of research, subject to constant tension and change. Today, though, no-one would dispute the fact that History of Education, as an important part of human activity, is historical study which is necessary in order to comprehend the past and present of societies and of humans themselves, in concert with the study of other aspects of human life. Historically, History of Education has been a field of research that is open to other historians in general, or sector-specific historians in particular, including to different professionals in the world of education. In view of the twofold configuration of History of Education - as a discipline and as a field of research within the academic area of Educational Sciences - it can be identified as one more sector-specific history; as a historical discipline whose field of study and analysis is education, as stated by Viñao (2003). From this perspective, we cannot view History of Education merely as a disciplinary field designed to draw lessons from the past, in the form of formulae and prescriptive "recipes". The work of the educational historian must focus on the ability to make audiences think, rethink and interpret the reality of education from a historical perspective. The purpose of History of Education is to shed light on the schooling system as it currently stands; to help people to understand that system and operate within it.

The History of Education as a field as we know it today, in terms of how it is viewed in the academic world, has undergone significant change in comparison to the parameters of the last century. The emergence of new fields of research, including the study and reconstruction of schoolroom events and strategies, means we can now carry out novel and renewed contemplations of the fact of education throughout history. The inclusion of the ethnographic paradigm is opening doors to new and promising areas of research in History of Education, which is having an undeniable impact in the epistemological enrichment of the discipline it. History of Education, alongside museology as an academic discipline, is continually revealing new revisions and a cultural recognition of schooling. (MOLERO; MOLERO, 2003). The schooling system, as the source of students' own individual culture, helps to build knowledge of the personal and collective processes taking place within their own environment. These authors agree with the view that "school has its own culture, and its historical contribution cannot be truly appreciated through the simplistic image of a sounding box for the ideological and social phenomena surrounding it". (MOLERO; MOLERO, 2003, p. 849).

The renewal of educational historiography in general involved the prelude to a new and necessary History of Education. From the 1980s onwards, in Spain, historians began to move past the traditional form of relating history, centred on positivist paradigms. In the 1990s, new ways of looking at education in the past emerged, and it was in 1995 that Dominique Julia described school culture as a historical object, as: 
A set of norms which define the knowledge that is to be imparted, the behaviours to be inculcated, and a set of practices which facilitate the conveyance of that knowledge and the incorporation of those behaviours, with those norms and practices being orientated toward goals which may vary from period to period religious, socio-political goals or simply that of socialisation. (JULIA, 1995, p. 354).

Later on, Depaepe and Simon (1995) highlighted the possibilities that this historical focus offered in helping to decipher the codes of the "black box" which was the day-to-day reality of education. As is pointed out by Moreno Martínez (2009), in the early $20^{\text {th }}$ Century, the new cultural history of education - through its ethnographic and micro-historical aspects - encouraged research into the material- and immaterial culture of the school (YANES, 2007), establishing it as a nascent field in historiography. In the 1980s, Sacchetto (1986) highlighted the usefulness of gleaning information from what he calls "objetos-huellas" (loosely translatable as "artefacts"), understood as historical products imbued with the cultures which shaped the school system. These artefacts are objects which tell us something about the past to which they belong. Specifically, these are amongst the questions which helped to construct a broader, overarching history of schooling.

In light of these renewed tendencies in pedagogical historiography, in keeping with the ideas of López Martín (2013, p. 18), let us recognise the special interest currently held by "the study of the school as a social space which is constructed with its own culture, capable of reshaping the influx of external factors, and thus accounting for a large of part of the structure of its internal organisation". This focus, known as school culture, has given us a new dimension in the area of teaching and research in History of Education. As Escolano states:

The material culture of the school - a sort of objective register of the so-called empirical culture of the education institutions, is the visible exponent, and also the interpreted effect, of the signs and meanings exhibited by so-called artefacts, and also the representations which reproduce or accompany them - intuible, handleable sources in which pedagogical tradition has been recorded. (ESCOLANO BENITO, 2007, p. 15).

In terms of the attempt to establish relations between the study of school culture and "Museology of Education", it is useful to lay down a few basic considerations, before stating them within the framework of History of Education. We know that the earliest museological treaties are practically coetaneous with the origin of museums. Museology is a science which studies the relations between human beings and their environment, and brings with it the expression, promotion and affirmation of various forms of identity. It involves the study of museums, and also the reflexive analysis of the museographic phenomenon. Nevertheless, museology as such, though it is a young branch of science, in continuous development and in the process of consolidation, has already covered a significant amount of ground. Hernández (2007, p. 5), points out that "museology as a new science must give us the strategy which best serves us to take care of, protect and communicate heritage". Its inclusion on university syllabi and in post-university activities, along with a large number of specialised publications on the topic, demonstrate the sway the subject currently holds. The museum is the subject of study, both for museology and for museography, but whilst for the former, it is a formal and material object, for the latter it is a physical object to which the principles and rules governing museology are applied. 
There are many research teams, societies, professional associations, etc., who are doing a fine job of promoting and driving forward the necessary museological studies. (LORENTE, 2012). Undeniably, the circumstances and sociocultural projection of museums are an increasingly relevant phenomenon in today's society, which is being studied by such disparate academic disciplines as Anthropology, Sociology, Art History, Architecture and Pedagogy, amongst many others. Museums are clearly a pluridisciplinary phenomenon.

Gradually, the organisation, structure and operation of museums have become more professional, dealing with political, cultural and social requirements, and also with ethical, didactic and communicational obligations never before encountered. In line with Poulot (2011), this author holds that belief that the analysis of the museum as an institution lies at the crossroads between Anthropology of Culture, Sociology of Work or of Organisations, and History of Objects.

It is worth also bearing in mind the contributions made by New Museology for museums in the 1960s. The steps taken by this movement gradually - or, in some cases, more radically - brought change to museums which had generally settled into the comfortable status of reference institutions, and mere containers for memory. New Museology became an important starting point for realising the change that the museum required, and has become enriched and transformed with the social- and cultural changes, and with the expectations of the audiences who use museums. (ALONSO FERNÁNDEZ, 2012). It must be admitted that with New Museology and Georges Henri Rivière, emphasis was placed on the social function of the museum, on the desire to understand it as an institution in the service of society, and on its interdisciplinary nature. The museum itself had to adapt to its visitors, and attempt to hold a dialogue with the society it served. We can state that, with New Museology, more importance is attached to the relatively recent development of Museums of Education in Spain.

A little later on, Critical Museology, which had been born in the 1970s at the Reinwardt Academy in the Netherlands and remained present ever since, went beyond the communicative aspect of the institutions and the pieces, analysing the historical determinations of that quality. It arose from the persistent crisis in the concept of the museum as a space for interaction between the public and a collection, and as a consequence of a cultural policy. (LORENTE, 2006). Rather than a unique interpretation of an artefact, Critical Museology opts for self-led discovery and learning on the part of each individual visitor. Critical Museology views the museum as a qualitative, networked institution, in charge of negotiating cultural meanings with the help of teams and personnel to forge relations and collaborations with social groups. It looks at the relations which museums establish with the populace, emphasising its educational, civic and social role, and stating the ways in which contexts can draw advantages and found projects which make these institutions somewhat more democratic.

Museology of Education is a young scientific discipline which includes the work of studying the specific museistic relation of people with reality and the act of education. The task of the education museologist is to establish what can be considered heritage in this environment and what cannot; what types of heritage exist and how can they be safeguarded; what is the usefulness or possibilities they offered us for research and teaching in History of Education; which audiences need to be catered for, and in what way, etc. Only what is known and valued will be protected and conserved. Museology of Education, from 
the material and immaterial nature of heritage, must contribute to lending value to both pretend and true stories from childhood and adolescence in school in the past. Memory is heritage, and heritage is education. Hence, neither memory nor educational heritage can be dissociated from History of Education.

In view of this outlook in museology, in the past two decades, there has been a significant development of museums in general, and Museums of Education in particular. Especially, in recent years, in History of Education, there has been an extensive movement in favour of Museology of Education, historical studies about particular eras and educational experiments and about the recovery and exhibition of the remnants of the school of the past. Education historians, in the attempt to construct this Museology of Education, are reflecting about the concept, aims and objectives that must guide the Museum of Education, and on the way how the past of education may contribute to the reconstruction of the different historical educational processes.

Museology of Education in Spain is rooted mainly in the late 19th Century, in 1882, with the creation of the so-called Museo de Instrucción Primaria (Primary Education Museum), and later the Museo Pedagógico Nacional (National Pedagogical Museum). (GARCÍA DEL DUJO, 1985). From then on, right up until the present day, with certain specific stops along the way, the discipline has gradually evolved, in connection with the founding of recognised Museums of Education across the whole of Spain. It was in 2004 that Museology of Education, linked to the trajectory of new museology in Spain, it was consolidated more consistently in the country, thanks to the founding of the Sociedad Española para el Estudio del Patrimonio Histórico Educativo (Sephe) ${ }^{3}$, and its consequent support and backing for the various initiatives aimed at studying, recovering, promoting and giving a special protagonist role to educational heritage.

At present, Museology of Education in Spain as an academic discipline, is at a very important point of construction and progressive growth. Particularly noteworthy is the effort of public and private awareness-raising which is taking place in our society, helping to recover and highlight a significant number of historical educational facts that were unknown, forgotten or simply silenced. Today, Museology of Education in Spain, in relation with Didactics as a science, continues to be involved in the construction of pedagogy surrounding our historical educational heritage, with the aim of exhibiting it, teaching it, highlighting its importance and disseminating it. The purpose is to develop heritage education (FONTAL, 2013) which, from an emotional and sentimental point of view (ÁLVAREZ DOMíNGUEZ, 2013), helps us to interpret and expressively seek interpretation of the historical accuracy of school education. If Museology of Education did not contribute, through Museums of Education:

to making us a little more human; if it did not bring us closer together; and if it did not break with the structures which have, for so long, served more to divide and separate people than to bring them together in brotherhood, its social function could not be realised, and it would have no true raison d'être. (SOLA, 2001, p. 58).

In line with Ruiz Berrio (2006), this author is inclined to stay that at present, relations between Museology of Education and History of Education are encouraged by the nature of

\footnotetext{
${ }^{3}$ See <www.institucional.us.es/paginasephe>. Website of Sociedad Española para el Estudio del Patrimonio Histórico Educativo (Sephe).
} 
both disciplines and by their postmodern focus.

Over the past twenty years in History of Education, we have seen a genuine revolution in the sources on which work must be based, starting with the degree of respect gained amongst researchers for the principle of consulting not just one source, but all possible sources, and of these sources, pride of place is given to the material culture of the school: buildings, furniture, didactic material, images, etc. (RUIZ BERRIO, 2006, p. 289).

As López Martín points out, the objective of research into educational heritage must focus on "puzzling out the school culture based on the interpretation of material culture". (LÓPEZ MARTíN, 2013, p. 34). Therein lies the significant challenge faced by History of Education, with the help of Museology of Education and Heritage Education. Brunelli (2014) reminds us that the interpretation of heritage is now an emerging discipline which, making use of different teaching methods and various communication techniques, has the function of guiding the audience in discovering and defining the different heritage spaces.

\section{Historical educational heritage as a source for research in the History of Education in Spain: evidence and breakthroughs}

Today, we cannot deny that the restrictive vision of heritage - monumental and artistic - has been surpassed. (MAYORDOMO, 2014). Although we belong to a society where there is a fervent drive to archive and collate everything around us, we understand that school material satisfies a series of requirements, and is therefore worthy of the treatment appropriate to a museum. (DACOSTA, 2008). The study and museum curation of educational heritage today in Spain is an important field of researchers for education historians.

The schooling system as it was has left us a set of material utensils, a set of teaching materials, which is the best possible reflection of its empirical culture and of the tradition ascribed to the historical office of teacher, along with the need to learn. This material, which has traditionally been being exhibited for over a century in Museums of Education and/or School Memory Centres, enjoys the recognition of all society and of education historians, who view it as a scholarly resource. It is undeniable that the study of school materials has opened up a new historiographical field for education historians in Spain, who carefully study the way in which subjects create, construct and use the artefacts that represent the material culture of a given age. Schools have never ceased to be spaces in which material cultures are constructed, and we know that material history can only be constructed on the basis of artefacts which have their own meanings, and which we must learn to decipher. The task of the material historian is to find artefacts' relation with their contexts of creation and use, attempting to compile an iconography of items appropriate for their roots. (ESCOLANO BENITO, 2007).

Educational heritage, being the visible part of education's past, is a useful tool which we can use to discover, study and interpret the history of educational events. This heritage is an asset, which is worthy of being publicly exhibited for all to see. Constructing and communicating the values of memory is a public responsibility, and also a task in which education historians have to play an important role of interpretation, dissemination and study of the forms and social effects of public uses of memory.

Hereafter, we shall plot and present a series of evidence and breakthroughs, which 
will demonstrate that the study and recovery of educational heritage in Spain is a novel field of study for education historians, which will draw the attention of multiple researchers and research teams:

\section{a) Establishment of the Sociedad Española para el Estudio del Patrimonio Histórico Educativo (Sephe) and other associations}

The Sociedad has been on the Spanish Ministry of the Interior's National Register of Associations since $2004^{4}$. It is made up of a total of approximately 100 private and institutional members, and its most significant activities include: the publication of an annual newsletter (Boletín Informativo - Bisephe) ${ }^{5}$; the biannual holding of Science Days ${ }^{6}$; the running of the "Manuel Bartolomé Cossío" Prize for educational heritage ${ }^{7}$; the gathering of aid to stage activities relating to educational heritage ${ }^{8}$; and the upkeep of a website to keep those interested in the study of educational heritage informed ${ }^{9}$.

As an example of associations set up in relation with educational heritage, we can point to the case of the Asociación Universitaria para la Conservación y Estudio del Patrimonio Educativo (Aucepe), founded in 2012 at Seville University.

\section{b) Publications of flagship studies and other work pertaining to historical educational heritage}

In the past fifteen years, especially, the number of papers and publications relating to the study and recovery of educational heritage has grown massively ${ }^{10}$. Even at the risk of excluding important authors, we wish to draw special attention to the role of the fundamental work carried out by Professors Ruiz Berrio, Escolano Benito, Viñao Frago, Moreno Martínez, López Martín, Hernández Díaz, etc. In particular, we can point to the seminal work of Professor Ruiz Berrio in 2009. (RUÍZ BERRIO, 2009).

It is also important to point out the large number of academic journals which have devoted a monographic edition to this subject. We refer, for example, to journals such as: Educación XXI ${ }^{11}$, Participación Educativa. Revista del Consejo Escolar del Estado ${ }^{12}$, Revista de Ciencias de la Educación. Órgano San José de Calasanz ${ }^{13}$, Arbor. Ciencia,

4 The Sociedad's statutes can be consulted at: <http://institucional.us.es/paginasephe/cosaspdf/ ESTATUTOS.pdf>.

${ }^{5}$ See <http://institucional.us.es/paginasephe/actividades.html>. Readers can download the various bulletins that have been published.

6 See <http://institucional.us.es/paginasephe/actividades.html>. Here, readers will find the subjects and characteristics of the various science days that have been held.

7 See <http://institucional.us.es/paginasephe/cosaspdf/cosaspdf/Premio\%20Cossio\%202017.pdf>. Readers can, for example, consult the Premio Cossío database, 2017.

8 See <http://institucional.us.es/paginasephe/cosaspdf/Convocatoria\%20Ayudas\%20Sephe\%202017.pdf>. For example, readers can consult the Call for Aid for the holding of Activities related to the Study and Recovery of Historical Educational Heritage, 2017.

${ }^{9}$ See <http://institucional.us.es/paginasephe>. SEPHE website.

10 In this respect, for example, the author suggests consulting a bibliographical document compiled by Professors Álvarez Domínguez and Payà Rico, available at: <https://drive.google.com/file/d/0BxrixJ2Eu6 JOakprNXJ1eW5US2EwV3doTG8wdndNZw/view?pref=2\&pli=1>. An up-to-date bibliography is also published each year in the newsletters of the Sephe: <http://institucional.us.es/paginasephe/ actividades.html>.

11 Issue 28, 2010. Monograph: "Patrimonio y educación".

12 Issue 7, 2008. Monograph: "Historia de un olvido: patrimonio en los centros escolares".

${ }^{13}$ Issue 232-233. Monograph: "Pensar y sentir la escuela. Patrimonio Histórico Educativo". 
Pensamiento y Cultura ${ }^{14}$, Cuestiones Pedagógicas ${ }^{15}$, Aula ${ }^{16}$ etc. Finally, it must be pointed out that in 2009, Cabás. Patrimonio Histórico Educativo ${ }^{17}$ was founded - the first journal specialising in the study of educational heritage, published by the Education, Culture and Sports Council of the Government of Cantabria, which has, to date, published fifteen editions.

\section{c) Research groups and competitive R\&D\&I projects}

Amongst the numerous groups for educational historical research which exist at the various universities in Spain, it must be noted that many of them have begun pursuing an avenue of research pertaining to historical educational heritage, through the development and implementation of R\&D\&I projects in various topical areas.

It is important to point out a few outstanding topics which are being studied by various research groups at different Universities: Gender and museology of education. Universidad Complutense de Madrid; Science and educational heritage in Secondary Schools. CSIC. Madrid; Photographs, images and memory of education. Universidad de las Islas Baleares; Architecture, school furniture and scientific/pedagogical material. Universidad de Murcia; Virtual museology, immaterial heritage and teaching of heritage. Universidad de Sevilla; School textbooks as educational heritage. Uned and Universidad de Granada; Educational heritage and ICT. Universidad de Valencia; Virtual pedagogical museums and civic education. Universidad de Vic; School press and school notebooks as educational heritage. Universidad de Salamanca, Universidad de Alcalá de Henares and Universidad de Málaga; Educational heritage of religious orders. Universidad del País Vasco; etc.

\section{d) Holding of conferences and other academic events}

There have been multiple conferences and meetings held in Spain about the study and recovery of educational heritage since the founding of the Sephe. Especially significant, because of the topics discussed, have been the academic events organised biannually by the Sociedad. Since 2005, seven such events have been held in cities such as Santiago de Compostela; Berlanga de Duero, Soria; Huesca; Vic; Barcelona; Murcia; Madrid and San Sebastián ${ }^{18}$.

In addition, all over Spain, there have been various national and international conferences and seminars, which have contributed in particular to sparking education historians' interest in studying the heritage and memory of education. Especially noteworthy on this topic is the University of Seville, which is continuously organising conferences on this topic ${ }^{19}$.

\footnotetext{
14 Issue 749, 2011. Monograph: "La enseñanza secundaria en construcción a través de los institutos históricos madrileños".

15 Issue 22, 2012-13. Monograph: "Cultura escolar y patrimonio histórico educativo".

16 Issue 22, 2016. Monograph: "Museismo pedagógico".

17 See <http://revista.muesca.es>.

18 The topics dealt with at each of these events can be found at: <http://institucional.us.es/paginasephe/ actividades.html>.

19 Particularly noteworthy are the seminars on the study and recovery of historical educational heritage, of which five have been held. A great deal of interest has been sparked by the inter-university sessions on pedagogical museums and the international conferences on museology of education. All of these activities
} 


\section{e) Staging of pedagogical exhibitions and publication of catalogues}

A great many pedagogical exhibitions held in the past two decades demonstrate the interest which, especially in university spheres, is being invested in this area ${ }^{20}$. Education historians have found a good way to convey samples of educational heritage to the populace. Some permanent exhibitions, and other temporary ones, are proving to be key elements that denote the preoccupation, in History of Education, to safeguard, exhibit and openly broadcast the materials, silences, voices, traces and forgotten aspects of the education of the past. Especially attractive are the roving exhibitions, commissioned by educational heritage collectors Jesús Asensi and José Antonio Mañas ${ }^{21}$. In addition, we must not forget the willingness of these two who, besides contributing to the design and setting up of exhibitions, are making efforts to obtain funding to render the contents more visible, by the publication of catalogues.

\section{f) Study of educational heritage in regulated training}

The consolidation of the study of educational heritage in Spain as an avenue of investigation has led to its introduction as specific content on training courses for future professional educators. Thus, in the Faculties of Education at Spanish universities, there is a varied curriculum being developed in relation with this topic. To begin with, as regards postgraduate courses, it must be noted that new doors are opening up for doctoral candidates to research this topic. Around ten doctoral theses on educational heritage have been defended in Spain in the past decade ${ }^{22}$. Secondly, specific Masters courses connected to this subject have emerged ${ }^{23}$, with widespread uptake among the student body. Thirdly, a number of study programmes in Educational Sciences have included modules relating to educational heritage ${ }^{24}$. Fourthly, we must highlight the development of educational innovation projects which, in close relation with school heritage, are being implemented in the country's Education Faculties ${ }^{25}$. Fifthly and finally, it must be noted that specialisation courses and post-university courses are being held on the subject ${ }^{26}$.

are referenced in the Sephe newsletters. See <http://institucional.us.es/paginasephe/actividades.html>.

20 The majority of these exhibitions are reviewed in the SEPHE newsletters, in the "Exposiciones Celebradas" (Exhibitions) section. See <http://institucional.us.es/paginasephe/actividades.html>.

${ }_{21}$ See <https://www.google.pt/?client=firefox-b\#q=Jes\%C3\%BAs+Asensi+y+Jos\%C3\%A9+Antonio+Ma\%C3 $\%$ B1as.+exposiciones\&gfe_rd $=\mathrm{cr}>$.

${ }^{22}$ This information can also be found in the SEPHE newsletters. See $<$ http://institucional.us.es/paginasephe/ actividades.html>.

${ }^{23}$ Of particular note is the Máster Universitario en Memoria y Crítica de la Educación, offered by Universidad de Alcalá de Henares and Uned, which includes modules such as: Ethnography and school culture; Memory, identity and citizenship; Material- and immaterial educational heritage; Iconography of education; Memory of school, gender and identities; Autobiography and voices from the school; Museology of Education. See <http://portal.uned.es/portal/page?_pageid=93,53594840\&_dad=portal\&_schema= PORTAL\&idMaster $=230901>$.

${ }^{24} \mathrm{~A}$ good example is the optional fourth-year module on the Degree in Pedagogy: "Cultural- and educational heritage: pedagogy and memory" at the Universidad de Murcia. See <https://aulavirtual.um.es/ umugdocente-tool/htmlprint/guia/RpQc8ZrvOTKGsOJaUsVJ5vliBZJPiUdZbV5SIJyi0458N0UhhEy>.

${ }^{25}$ At the University of Seville, we can point to innovative pedagogical projects relating to topics such as: oral sources and memory of education; recreating the educational past through school photos; new technology and educational heritage, etc.

${ }^{26}$ For instance, at the University of Seville, the following post-university extension courses, taught at the Centro de Formación Permanente, are of particular note: "Education and training in the context of the museum. The use of the pedagogical museum as an educational resource"; "Museum pedagogy: didactics, virtuality and dissemination of historical-educational heritage"; and "Museums and education: didactic possibilities for the dissemination and interpretation of cultural- and historical-educational heritage". Recently, a summer course 


\section{g) Exploitation of ICT and the potential of Web 2.0 for the dissemination of educational heritage}

The use of ICT, along with the dissemination possibility offered by Web 2.0, is facilitating the internationalisation of the study of Spain's educational heritage at all levels. Particularly noteworthy is the creation of www.patrimonioeducativo.es, which is a Virtual Classroom for the Teaching of Historical Educational Heritage. It is a meeting place, of everyone and for everyone, where they can share and actively participate, through the web, in the recovery and study of educational heritage (ÁLVAREZ; PAYÀ, 2013). It is also important to point out the role of internationalisation of educational heritage activities, taking place through social networks (Facebook ${ }^{27}$, Twitter ${ }^{28}$ and Histoedu ${ }^{29}$ ). Alongside this, we must recognise the possibilities offered by virtual museology to popularise Spain's educational heritage. These possibilities have been exploited, to build and run virtual museums.

\section{h) Toward the construction of Didactics of Educational Heritage}

Education and Heritage constitute an emerging binomial in the sector of Spain's cultural politics. (PLAN NACIONAL DE EDUCACIÓN Y PATRIMONIO, 2013). Teachers of History of Education, alongside the teaching departments of Museums of Education, are working in the right direction, aiming to make educational heritage an emerging pedagogical resource in the service of educational historical science and society. There are many didactic proposals in Spain which, in raising popular awareness of recovery and valuing of educational heritage, are having positive results, including in international museistic contexts. Recently, Professors Álvarez, Núñez and Rebollo have directed the documentary "El Museo Pedagógico de la Facultad de Ciencias de la Educación de la Universidad de Sevilla; un espacio para compartir historias" (2014) (The Pedagogical Museum of the Educational Sciences Faculty at the University of Seville; a space to share stories/histories), which is a worthwhile example of good practices in this field ${ }^{30}$.

\section{i) Founding of new Education Museums, Schooling Museums and/or Educational Heritage Centres, and promotion of the importance of those already in place}

Over the past twenty years, in particular, Spain has seen a notable increase in the number of museological projects which are of pedagogical and historic-educational nature, in terms both of their physical and virtual dimension. (COLLELLDEMONT, 2010). There are some very extensive ones, and others less ambitious, but nonetheless valid and enriching. We must highlight the role that Spanish universities are playing through the founding of Museums of Education in university contexts. (ÁLVAREZ; PAYÁ, 2014). In addition, it is important to recognise the work of the historical centres of both primary and secondary

has been held at the Universidad de León: "El patrimonio en educación: los edificios escolares" (Heritage in education: school buildings). See <https://paradafacultativa.com/2016/05/25/curso-de-verano-el-patrimonioen-educacion-los-edificios-escolares $>$.

${ }_{27}$ See $<$ https://www.facebook.com/patrimonioeducativo> .

28 See <https://twitter.com/patrimonioeduca>.

${ }^{29}$ See $<$ http://histoedu.es $>$.

30 See <http://tv.us.es/el-museo-pedagogico-de-la-facultad-de-ciencias-de-la-educacion-de-la-universidadde-sevilla-un-espacio-para-compartir-historias>. 
education, which, being sensitive in this field, are preserving educational heritage by the creation of Classrooms and/or School Museums. Furthermore, Historical School Classrooms are being recreated in many Ethnographic Museums. The next section lists the various pedagogical museum projects existing in Spain at time of writing, though there is the inevitable risk of overlooking some worthy initiative.

\section{Museums of Education in Spain: tradition, present and future}

School objects and their iconographic representations have now come to be viewed as identifying assets and values of our social and cultural lives. Material and immaterial cultures are gaining a high level of public interest, "becoming a central objective for the strategies of recovery and exhibition of a heritage which must be preserved, studied and disseminated". (ESCOLANO BENITO, 2007, p. 16). During the phase of startup and consolidation of the national educational systems, pedagogical museums will feed on the items, images and texts which have previously been publicly exhibited at universal exhibitions, such as the Great Exhibition in Paris in 1851. (GARCÍA DEL DUJO, 1985). Universal exhibitions constitute an emerging field of investigation, which is rich and attractive for historians of the school's material culture.

The relations between museum and memory are of fundamental importance. It is impossible to conceive of a museum without the existence of memory. "The items that are conserved are capable of containing, within themselves, the collective memory of peoples, which is why all cultures consider them to be true elements of memory, representative of a way of being in, and with, the world". (CARREÑO, 2007, p. 101). In order to recover the memory of education, we need to recreate yesterday in today's world, taking advantage of scholarly material from the past. We recognise that the accumulation of objects is not a museum's only function, devoting itself solely to the study of memory; instead, it needs to be open to the relations of the subject with the community. A museum today is a place where new generations can recognise their present as having evolved from the past.

When we look at Museums of Education in Spain from a historical perspective, the impression gained is of the existence of an overwhelming surge in the number of museums, exhibitions and exhibition spaces devoted to the culture and memory of school as a political, social and cultural institution. In recent times, the landscape of education museums has been significantly enriched by the establishment and opening of new Museums of Education extending across the whole of Spain. These museums, which are in a phase of expansion, have not only grown in number and uniqueness, but also, they have been capable of opening up to society, renovating their exhibition spaces and discourses, and applying, and making pay, an interesting policy of cultural dissemination with a view to making the peculiarity of historic educational heritage accessible to all of society. (SOMOZA RODRíGUEZ, 2011).

Museums of Education in Spain, in addition to preserving and actively recovering educational heritage, are being widely used as a pedagogical resource for teacher training. The role of these museums is to fill in the memorial blanks concerning the school institutions by used objects passed down from yesteryear. (ESCOLANO BENITO, 2007). However, they still need to continue to work with local and regional tourist networks, which help them to raise awareness of the value of a branch of museology which is not yet sufficiently well known and appreciated by society.

In Spain, on the one hand, many Education Departments in the Autonomous 
Communities have, at one point or another, weighed up the museistic possibilities offered by their educational heritage to create a regional Museum of Education. However, largely for financial reasons, not all cases have let to the establishment of a museum. On the other hand, thanks to many other initiatives, both public and private, various spaces of different types, where a sample of educational heritage is preserved, exhibited and broadcast. We can state that in Spain, the typology of existing Museums of Education is highly diverse. (RUÍZ BERRIO, 2006). In our case, we shall opt to highlight four types of museums, distinguishing them on the basis of the origin of their foundation and/or creation: a) Political decision (Ministries, Councils, Provincial Authorities, Municipal Authorities, etc.); b) Academic and institutional origin (universities, teacher groups, directive teams, school privy councils, school governing boards, societies, foundations, etc.); c) Private initiative. (Individuals, family, group, etc.); d) Associationism, social groups, community engagement and civil participation (groups and/or social collectives, associations and communities, and other types of civic-participation groups). Below, in an attempt to update and further previous works on this subject (RUÍZ BERRIO, 2006; GONZÁLEZ GÓMEZ, 2008; CARREÑO, 2008; GARCÍA GONZÁLEZ, 2010; MORENO MARTÍNEZ, 2015), following a substantial effort to locate resources, we present a list covering Museums of Education, Classes and/or Centres of Educational Heritage, throughout the different Autonomous Communities in Spain. This represents a large number of projects which have been realised, and which continue to employ a significant number of people to ensure a brighter future for the study, recovery, exhibition and promotion of educational heritage.

Table 1 - Education museums and/or Centres of Educational Heritage in Spain.

\section{EDUCATION MUSEUMS AND/OR CENTRES OF EDUCATIONAL HERITAGE IN SPAIN}

\section{Andalucía}

- Museo Pedagógico de la Facultad de Ciencias de la Educación de la Universidad de Sevilla (Seville).

- Museo Pedagógico de la Universidad de Huelva (Huelva).

- Museo Pedagógico del CEIP. "Altos Colegios. Macarena" (Seville).

- Museo Andaluz de la Educación (Alhaurín de la Torre, Málaga).

\section{Aragón}

- Museo Pedagógico de Aragón (Huesca).

- Museo Pedagógico de Teruel. Centro Rural de Innovación Educativa (Criet) de Alcorisa (Alcorisa, Teruel).

- Centro Museístico de la Escuela Rural Linás de Marcuello (Linás de Marcuello, Huesca).

\section{Asturias}

- Museo de la Escuela Rural de Asturias (Viñón, Cabranes).

- Museo Escolar Selgas. Fundación Selgas-Fragalde (El Pito - Cudillero, Asturias).

- Aula Museo de la Escuela Rural del C. P. Aurelio Méndez (San Antolín de Ibias, Asturias).

- Museo Etnográfico de Quirós (Asturias).

\section{Cantabria}

- Centro de Recursos, Interpretación y Estudios de la Escuela (Crieme) (Polanco).

- Aula Museo “D. Ángel Fernández de los Ríos” (Pesquera).

- Museo Escolar C. P. "Agapito Cagiga" (Revilla, Camargo).

- Museo de la Escuela Rural de Mogrovejo (Camaleño, Santander). 


\section{Castilla La Mancha}

- Museo Pedagógico y del Niño de Castilla La Mancha. "El Museo del Niño de Albacete" (Albacete).

- Núcleo expositivo: "Un siglo de escuela" (Santa Cruz de la Zarza, Toledo).

\section{Castilla y León}

- Centro Internacional de la Cultura Escolar (Ceince) (Berlanga de Duero, Soria)

- Centro Propio Museo Pedagógico de la Universidad de Salamanca (Zamora).

- Museo Pedagógico de Otones de Benjumea (Otones de Benjumea, Segovia).

- Museo Editorial Hernando (Aldeanueva de la Serrezuela, Segovia).

- Museo Escolar de Bordecorex (Bordecorex, Soria).

- Museo Pedagógico "La Escuela de Antaño" (Aldeamayor de San Martín, Valladolid).

- Museo Pedagógico de Ciencias Naturales "Jesús María Hernando Cordobilla" (Valladolid).

- Museo de la Escuela "Venancio Blanco" (Matilla de los Caños del Rio, Salamanca).

- Escuela-Museo de Vega de Doña Olimpa (Saldaña, Palencia).

- Museo Pedagógico de Bañuelos de Bureba (Bañuelos de Bureba, Burgos).

- Fundación Sierra Pambley. Sala "Manuel Bartolomé Cossío" (León).

\section{Cataluña}

- Museo Universitario Virtual de Pedagogía de la Universidad de Vic (Muvip) (Vic, Barcelona).

\section{Community of Madrid}

- Museo Laboratorio de Historia de la Educación "Manuel Bartolomé Cossío" (Madrid).

- Museo de la Escuela Rural de Tielmes (Tielmes, Madrid).

- Museo Pedagógico de Los Santos de la Humosa (Los Santos de la Humosa, Madrid).

- Museo Pedagógico “Jesús Asensi”. Universidad Autónoma de Madrid (Madrid).

- Museo Pedagógico de Arte Infantil. Facultad de Bellas Artes de la Universidad Complutense de Madrid (Madrid).

- Museo Virtual de Etnografía Escolar en la España Contemporánea. Universidad Complutense de Madrid (Madrid).

\section{Community of Murcia}

- Museo Virtual de Historia de la Educación (Muvhe) (Murcia).

- Centro de Estudios de la Memoria (Ceme) de la Universidad de Murcia (Murcia).

\section{Community of Valencia}

- Seminario de Historia de la Escuela de la Facultad de Magisterio de la Universidad de Valencia (Valencia).

- Escuelas antiguas de Sesga (Ademuz, Valencia).

- Escuelas antiguas de Aras de los Olmos (Aras de los Olmos, Valencia).

- Museo Escolar Agrícola de Pusol (Elche, Alicante).

- Aula de la Escuela - Museo Etnográfico Municipal (Biar, Alicante).

- Aula Museo "Carles Salvador" (Benassal, Catellón).

- Antigua Escuela Mas de Sales Matella (Culla, Castellón).

- Escuela del Mas d'en Ramona (Les Coves de Vinromà, Castellón).

\section{Extremadura}

- Centro de Interpretación de la Cultura Escolar (Cabezuela del Valle, Cáceres).

\section{Galicia}

- Museo Pedagógico de Galicia (Santiago de Compostela).

- Museo de la Escuela y de la Infancia (A Pobra de Trives, Ourense).

- Museo de la Fundación Vicente Risco (Allariz, Ourense).

- Museo "Manuel Reimónez Portela" (A Estrada, Pontevedra). 


\begin{tabular}{|l|}
\hline Balearic Islands \\
\hline - Archivo y Museo de la Educación de las Islas Baleares (Ameib) (Inca, Mallorca). \\
\hline Canary Islands \\
\hline - Museo de la Educación de la Universidad de La Laguna (Medull) (La Laguna. Santa Cruz de Tenerife). \\
- Museo de Historia de la Educación de la Palma "Germán González González". Centro Cultural Pérez \\
Andreu (Santa Cruz de la Palma). \\
- Museo Escuela del CEP de las Palmas de Gran Canaria (Las Palmas de Gran Canaria). \\
- Aula Museo Pedagógico del CEIP. "La Zarza" (Arico, Tenerife). \\
- Museo de la Escuela "Carmita Afonso" (La Aldea de San Nicolás, Las Palmas). \\
- Biblioteca-Museo Pedagógico del CEIP. "Alfonso X EI Sabio" (Güimar, Santa Cruz de Tenerife). \\
\hline Basque Country \\
\hline - Museo de la Educación de la Universidad del País Vasco (San Sebastián). \\
- Centro de Documentación sobre Historia de la Educación en Euskal Herria. Universidad del País Vasco \\
(San Sebastián).
\end{tabular}

Source: Compiled by autor.

\section{By way of conclusion: final thoughts}

From the past, we have inherited a set of voices, writings, icons and objects, which are an expression of the material- and immaterial culture of the school. We need to assess these bequests with an ethnographic and micro-historical eye in order to learn the value of pedagogical memory, of its practices and discourses, its tradition and potentialities. (ESCOLANO BENITO, 2007, p. 13).

The increasing study of educational heritage in Spain, and its use as a teachingand research resource for History of Education, has demonstrated the museological and museographic potential of the heritage legacy from the school of yesteryear. This new concept of school heritage is part of a renewed view of the historiography of education, with interest focusing on the intra-history of the school - i.e. the history "within the school". (LÓPEZ MARTÍN, 2001). Its materials are the object of historical educational knowledge, and afford us a great many possibilities for research in the field of History of Education. Furthermore, they are, in their own right, resources and instruments which help us to transmit and interpret educational knowledge from history.

In a society where all objects and materials from the past are easily cast aside and destroyed, there is an urgent need, and the commitment to recover historical elements is an important task which needs to be dealt with. Education historians must make a commitment to saving and safeguarding educational heritage, by creating museum-type spaces in which to conserve it, study it and disseminate it. (RUÍZ BERRIO, 2006). However, as Escolano Benito (2007) states, the reconstruction of the past of educational institutions and the creation of centres of educational memory are only justified and legitimate if they are done on the expectation of a future for communities who invest effort in driving forward these cultural projects, rather than sticking slavishly to the ritualistic practices of the past. Thus, new Education Museums need to stay connected to research, based on curiosity about the History of Education. From these museums, as historians and as pedagogues, it is up to us to make an effort in promoting historical knowledge as the basis for wisdom. (DAPEAPE; SIMON, 2014). 
In conclusion, we can state that Museology of Education in Spain is in a good state of health at present, and appears to have a bright future. It is a branch of museology which is under construction, which, alongside History of Education, can help us to better understand the world we live in, and the world of the school, "because society is present in each and every person as a whole, through language, norms, culture" (MORIN, 2001) and historical educational heritage.

\section{References}

ALONSO FERNÁNDEZ, Luís. Nueva Museología: planteamientos y retos para el futuro. Madrid: Alianza Editorial, 2012.

ÁlVAREZ dOMínGUEZ, Pablo (Ed.). Los Museos Pedagógicos en España: entre la memoria y la creatividad. Gijón: TREA and Editorial Universidad de Sevilla (EUS), $2016 a$.

ÁLVAREZ DOMÍNGUEZ, Pablo. Educar en emociones y transmitir valores éticos: un desafío para los Museos de Pedagogía, Enseñanza y Educación. Educació i Historia Revista d'Història de l'educació, n. 22, p. 91-114, july/december 2013.

Los Museos Pedagógicos en España: actualidad y perspectivas de futuro. In: ÁLVAREZ DOMíNGUEZ, Pablo (Ed.). Los Museos Pedagógicos en España: entre la memoria y la creatividad. Gijón: TREA and Editorial Universidad de Sevilla (EUS), $2016 b$. p. 21-32.

ÁLVAREZ DOMíNGUEZ, Pablo; PAYÀ, Andrés. Los Museos Pedagógicos Universitarios en España: tradición y futuro ante la difusión del patrimonio histórico educativo. Actas del Congreso Internacional: Museos Universitarios: Tradición y Futuro. Madrid: CIMU, 2014, p. 1-6.

Patrimonio educativo 2.0: hacia una didáctica histórico educativa más participativa y la investigación en red. Cuestiones Pedagógicas - Revista de Ciencias de la Educación, n. 22, p. 119-141, 2013.

BRUNELLI, Marta. Heritage interpretation. Un nuovo approccio per l'educazione al patrimonio. Macerata: EUM, 2014.

CARREÑO, Miriam. Los nuevos museos de educación, un movimiento internacional.

Encounters on Education, v. 9, p. 75-91, 2008.

. Museología y Museografía de la Educación. In: ESCOLANO BENITO, Agustín (Ed.). La cultura material de la escuela. En el centenario de la Junta para la Ampliación de Estudios 1907-2007. Berlanga del Duero (Soria): CEINCE, 2007. p. 91-110.

COLLELLDEMONT, Eulàlia. Los museos virtuales de educación en España. In: RUIZ BERRIO, Julio (Ed.). El patrimonio histórico-educativo. Su conservación y estudio. Madrid: Biblioteca Nueva, 2010. p. 275-293.

DACOSTA, Arsenio. Musealizar la tradición: reflexiones sobre la representación pública del pasado. Revista de Antropología Experimental, n. 8, p. 97-106, 2008.

DECLARACIÓN DE MÉXICO SOBRE LAS POLÍTICAS CULTURALES. Conferencia mundial sobre las políticas culturales. México D.F., 26 July - 6 August 1982. Online: <http://portal.unesco.org/culture/es/files/35197/11919413801mexico_sp.pdf/mexico_sp.pdf >. Last accessed: 8 June 2017.

DEPAEPE, Marc; SIMON, Frank. Is There any Place for the History of 'Education' in the 'History of Education'? A Plea for the History of Everyday Educational Reality in and Outside Schools. Paedagogica Historica, n. 30, v. 1, p. 9-16, 1995. 
Sobre el futuro del pasado de la educación. Museos de la Enseñanza y su relación con la Historia de la Educación - El caso de Ypres. In: BADANELLI, Ana M.; POVEDA, María; RODRÍGUEZ, Carmen (Eds.). Pedagogía museística: prácticas, usos didácticos e investigación del patrimonio educativo. Madrid: Universidad Complutense de Madrid and Sephe, 2014.

ESCOLANO BENITO, Agustín (Ed.). La cultura material de la escuela. En el centenario de la Junta para la Ampliación de Estudios 1907-2007. Berlanga de Duero, Soria: Ceince, 2007.

ESCOLANO BENITO, Agustín; HERNÁNDEZ DÍAZ, José María. La memoria y el deseo: cultura de la escuela y educación deseada. Valencia: Tirant lo Blanch, 2002.

FONTAL, Olaia. La educación patrimonial. Del patrimonio a las personas. Gijón: Trea, 2013.

GARCÍA DEL DUJO, Ángel. Museo Pedagógico Nacional (1882-1941). Teoría educativa y desarrollo histórico. Salamanca: ICE de la Universidad de Salamanca, 1985.

GARCÍA GONZÁLEZ, Francisco. Reseña de los Museos de la Educación españoles. Albacete: Museo del Niño, 2010.

GONZÁLEZ GÓMEZ, Sara. Recursos electrónicos para el estudio del museismo pedagógico. Foro de Educación, n. 10, p. 483-494, 2008.

HERNÁNDEZ, Francisca. La museología ante los retos del siglo XXI. E-rph, p. 1-26, December, 2007.

JUAN BORROY, Víctor (Ed.). Museos Pedagógicos. La memoria recuperada, Huesca: Gobierno de Aragón. Departamento de Educación, Cultura y Deporte. Museo Pedagógico de Aragón, 2008.

JULIA, Dominique. La culture scolaire comme objet historique. Paedagogica Historica, Colonial Experience in Education, Historical Issues and Perspectives, Supplementary Series (I), p. 353-382, 1995.

LÓPEZ MARTíN, Ramón. Historia de la Escuela y Cultura Escolar: dos décadas de fructíferas relaciones. La emergente importancia del estudio sobre el patrimonio escolar. Cuestiones Pedagógicas, n. 22, p. 17-42, 2013.

LÓPEZ MARTíN, Ramón. La escuela por dentro. Perspectivas de la cultura escolar en la España del siglo XX. Valencia: Universidad de Valencia, 2001.

LORENTE, Jesús P. Manual de Historia de la Museología. Gijón: Trea Ediciones, 2012. . Nuevas tendencias en la teoría museológica: a vueltas con la Museología Crítica.

Museos.es, n. 2, p. 231-243, 2006.

MAYORDOMO, Alejandro. Patrimonio cultural y educación: retos, posibilidades y compromisos. In: LÓPEZ, Ramón (Ed.). Educación y entorno territorial de la Universitat de Valéncia. Valencia: Vicerrectorat de Participació y Projecció Territorial de la Universitat de Valéncia, 2014. p. 25-34.

MEDA, Juri; BADANELLI, Ana María. La historia de la cultura escolar en Italia y en España: balance y perspectivas. Macerata: EUM, Edizioni Università di Macerata, 2013. MOLERO, Antonio; MOLERO, Valeria. Panorama de la museística escolar en Francia. In: JIMÉNEZ, Alfredo et al. (Eds.). Etnohistoria de la escuela. Burgos: Servicio de Publicaciones de la Universidad de Burgos, 2003. p. 839-849.

MORENO MARTÍNEZ, Pedro Luís. La Historia de la Educación como disciplina y campo de investigación: renovación historiográfica, patrimonio y educación. In: BERRUEZO, 
Reyes; CONEJERO, Susana (Eds.). El largo camino hacia una educación inclusiva. La Educación Especial y Social del siglo XIX a nuestros días. Pamplona: Universidad Pública de Navarra, v. III, 2009. p. 141-151.

. La historiografía del patrimonio educativo en España: un balance crítico. Educar em Revista, n. 58, p. 87-102, 2015.

MORIN, Edgar. Los 7 saberes necesarios para la educación del futuro. Barcelona: Paidós, 2001.

PAYÀ, Andrés; ÁLVAREZ, Pablo. Història de l'educació 2.0 i Història de l'e-Educació. Les TIC i les xarxes socials al servei de la docència historicoeducativa. Educació i Història, n. 26, p. 41-64, 2015.

. Historia y patrimonio de la educación 2.0: conocimiento compartido, recursos y propuestas didácticas. In: ESPIGADO, Gloria (Ed.). La Constitución de Cádiz. Genealogía y desarrollo del sistema educativo liberal. Cádiz: Sedhe and Universidad de Cádiz, 2013. p. 799-810.

PLAN NACIONAL DE EDUCACIÓN Y PATRIMONIO. Instituto del Patrimonio Cultural de España, 2013. Online: $<$ http://ipce.mcu.es/pdfs/PNEducPatrimonio.pdf>.

POULOT, Dominique. Museo y museología. Madrid: Abada, 2011.

RUIZ BERRIO, Julio. El patrimonio histórico-educativo. Su conservación y estudio. Madrid: Biblioteca Nueva, 2009.

Historia y museología de la Educación. Despegue y reconversión de los museos pedagógicos. Historia de la Educación - Revista Interuniversitaria, n. 25, p. 271-290, 2006.

SACCHETTO, Pier Paolo. El objeto informador. Los objetos de la escuela: entre la comunicación y el aprendizaje. Barcelona: Gedisa, 1986.

SOLA, Tomislav. Les ponts: un musée dans un contexte de mondialisation. Museum International, n. 209, p. 57-60, 2001.

SOMOZA RODRÍGUEZ, Miguel. Musealización del patrimonio educativo de los institutos históricos de Madrid. Propuestas para un museo virtual. Arbor. Ciencia, Pensamiento y Cultura, n. 749, v. 187, p. 573-582, May/June 2011.

VIÑAO, Antonio. La Historia de la Educación ante el siglo XXI: tensiones, retos y audiencias. In: JIMÉNEZ, Alfredo et al. (Eds.). Etnohistoria de la escuela. Burgos: Servicio de Publicaciones de la Universidad de Burgos, 2003. p. 1063-1074.

YANES, Cristina. El patrimonio educativo intangible: un recurso emergente en la museología educativa. Cadernos de História da Educação, n. 2, p. 71-85, 2007.

PABLO ÁLVAREZ DOMÍNGUEZ es Doctor por la Universidad de Sevilla (Premio Extraordinario de Doctorado). Profesor contratado doctor. Departamento de Teoría e Historia de la Educación y Pedagogía Social. Área: Teoría e Historia de la Educación. Secretario de la Sociedad Española para el Estudio del Patrimonio Histórico Educativo (Sephe). Secretario del Museo Pedagógico de la Facultad de Ciencias de la Educación de la Universidad de Sevilla.

Dirección postal: Facultad de Ciencias de la Educación, Universidad de Sevilla, C/ Pirotecnia, s/n., 41013, Sevilla, España.

E-mail: pabloalvarez@us.es 
Recebido em 02 de agosto de 2017.

Aceito em 21 de fevereiro de 2018.

(c) (i) 